\title{
„GARNIZONY ROZPROSZONE”? KILKA UWAG \\ O TERENACH GRUPOWANIA I MOBILIZACJI ARMII WANDALSKIEJ NA TLE POZOSTAŁYCH GERMAŃSKICH ŚRÓDZIEMNOMORSKICH „KRÓLESTW SUKCESYJNYCH” W V I VI WIEKU
}

\author{
Marek Wilczyński \\ Uniwersytet Pedagogiczny im. Komisji Edukacji Narodowej w Krakowie
}

\begin{abstract}
'THE SCATTERED GARRISONS'? A FEW REMARKS ON THE AREAS OF GROUPING AND MOBILIZATION OF THE VANDAL ARMY AS COMPARED TO OTHER GERMAN MEDITERRANEAN 'SUCCESSION KINGDOMS' IN THE $5^{\text {TH }}$ AND $6^{\text {TH }}$ CENTURIES
\end{abstract}

Principles of the troops dislocation and providing for the upkeep of the armies of the barbarian kingdoms in the Roman West in the $5^{\text {th }}$ and $6^{\text {th }}$ centuries are still under discussion. In the mid- $19^{\text {th }}$ century E. T. Gaupp claimed that the basis of barbarian settlement was assigning them one third of the cultivated land in provinces they settled. More than a century later, W. Goffart and J. Durliat completely denied and modified Gaupp's theory. In their opinion, the upkeep of the barbarian foederati was to be provided for from one-third of the provincial fiscal revenue allocated to the maintenance of the armed forces. However, a more thorough analysis of the source material proves it impossible to develop any universal pattern of settlement for all barbarian tribes. Military settlement of Vandals in Africa escapes the framework of the Gaupp model, but also that of the Goffart and Durliat model. King Gaiseric had completely seized the property of the Roman landowners in the vast area around Carthage and handed it over to his warriors, creating a strong garrison scattered over many square kilometers. The Vandal 'scattered garrison' maintained full mobilization efficiency and fulfilled all the functions of a garrison. The warriors were not paid wages, but granted the sustainable tax-free agricultural property. The article describes its functioning and compares it with solutions adopted in the other barbarian countries.

Key words: Late Antiquity, barbarian settlement, 'scattered garrisons', military of the $5^{\text {th }}$ and $6^{\text {th }}$ centuries.

Słowa kluczowe: późny antyk, osiedlanie barbarzyńców, „garnizony rozproszone”, wojskowość V i VI wieku. 
Od połowy XIX wieku próbowano zrekonstruować model osadnictwa wojskowego ludów barbarzyńskich w zajmowanych przez nie prowincjach Imperium Romanum. Jako pierwszy rozwiązanie zaproponował w 1844 roku Ernst Theodor Gaupp, przyjmując, że skoro źródła historyczne i pomniki prawa dotyczące królestw Ostrogotów, Wizygotów i Burgundów mówią o przydzielaniu barbarzyńcom jednej trzeciej dóbr na danym obszarze, to należy to rozumieć jako długofalową formę utrzymania wojsk barbarzyńskich przez oddanie im w sensie dosłownym jednej trzeciej (a w Galii nawet dwóch trzecich) majątków lokalnych rzymskich posiadaczy. Nawiązywał przy tym do rzymskiego prawa ius hospitalitatis, przewidującego obowiązek kwaterowania wojsk w dobrach prywatnych. Uważał też, że Wandalowie stanowili na tle innych ludów wyjątek, ponieważ swoje tereny osadnicze otrzymali nie na zasadach traktatowych, tylko prawem zdobywcy. Mimo respektowania różnic pomiędzy poszczególnymi królestwami przyjmowano jednak na ogół, że trzecią część ziem w zajmowanych prowincjach wojownicy germańscy przejmowali wraz z kolonami i inwentarzem w sensie dosłownym. Takiemu procesowi towarzyszyć musiały wywłaszczenia i tworzenie terenów osadnictwa barbarzyńskiego - zalążków późniejszych okręgów mobilizacji. Przełom w dyskusji stanowiły prace Waltera Goffarta i Jeana Durliata ${ }^{1}$, których tezy w dużym uproszczeniu sprowadzić można do odrzucenia zasady wywłaszczeń połączonych z rzeczywistym przydziałem ziemi i wykazania, że na utrzymanie wojsk barbarzyńskich wydawano trzecią część dochodów fiskalnych z terenów osadnictwa barbarzyńców, by zapewnić germańskim foederati środki utrzymania, a prowincjom cesarstwa w miarę „bezbolesne” przyjęcie przybyszów. Taki sposób utrzymywania wojsk barbarzyńskich konweniował z dotychczasową strukturą wydatków państwa rzymskiego i mógł sprzyjać utrzymywaniu osiedlania wojowników w tradycyjnej strukturze garnizonów, co jak się wydaje, działo się w obydwu królestwach gockich. Przyjmując jednak zasadę osiedlania barbarzyńców na nadanych im parcelach, trzeba założyć, że musiała powstać inna struktura mobilizacyjno-organizacyjna armii, „garnizony rozproszone”, których istnienia można się dopatrywać w królestwie Wandalów, a nawet u Swebów.

Strukturę i funkcjonowanie „garnizonu rozproszonego" widać najlepiej na przykładzie osadnictwa wojskowego Wandalów po zajęciu rzymskiej Afryki przez króla Gejzeryka. Inwazja Wandalów i Alanów na prowincje afrykańskie jest o tyle wyjątkowa, że źródła pozwalają w miarę precyzyjnie określić liczebność armii inwazyjnej,

W. Goffart, Barbarians and Romans. The Techniques of Accomodation, Princeton, New Jersey / Chichester, West Sussex 1980; J. Durliat, La salaire de la paix sociale dans les royaumes barbares ( $V^{k}-V^{\text {te }}$ siècles) [w:] Anerkennung und Integration. Zu den wirtschaftlichen Grundlagen der Völkerwanderungszeit 400-600, Hrsg. H. Wolfram, A. Schwarcz, Wien 1988, s. 21-72. Początkowo W. Goffart wyłączał ze swojej teorii Wandalów, ale w późniejszych pracach skłonny był już traktować ich tak samo jak inne ludy. Podobnie uważał J. Durliat (op. cit., s. 40 n.). Równolegle do ich ustaleń D. Claude przedstawił dowody wskazujące na to, że nie można wykluczyć ani nadań ziemi, ani wypłat z dochodów podatkowych, zob. D. Claude, Zur Ansiedlung barbarischer Föderaten in der ersten Hälfte des 5. Jahrhunderts [w:] Anerkennung und Integration..., s. 13-16. W najnowszej literaturze R. Steinacher (Die Vandalen. Aufstieg und Fall eines Barbarenreichs, Stuttgart 2016, s. 165 n.) dopuszcza możliwość zaopatrywania wojowników wandalskich w Afryce zarówno z dochodów skarbowych, jak i przez osadnictwo w wywłaszczonych majątkach rzymskich. 
która potem stanowiła siły zbrojne królestwa (natomiast mniej precyzyjnie da się określić siły obrońców) $)^{2}$. Możliwe, że jeszcze w czasie walk i oblężenia Hippo Regius (430-431 r.) król Wandalów tworzył na zapleczu prowizoryczne garnizony w celu zabezpieczenia dróg aprowizacji. Jest jasne, że zaopatrzenie w żywność było kluczem do wygranej w przeciągających się zmaganiach z komesem Afryki Bonifacjuszem ${ }^{3}$. Po kapitulacji miasta wczesną jesienią 431 roku i po pokonaniu na przełomie 431 i 432 roku wojsk rzymskich zasilonych kontyngentem posłanym

2 Dyskusja nad liczebnością i siłą bojową wojowników Gejzeryka i wojsk pozostających do dyspozycji Bonifacjusza ma długą tradycję i nie została jeszcze zamknięta. Warto przytoczyć tylko najważniejsze jej elementy, tym bardziej że także w dalszej argumentacji znajdą się odwołania do liczebności wojowników wandalskich w Afryce. Jeśli chodzi o Wandalów, to dwa źródła określają ogólną liczebność plemienia. Są to: Victor Vitensis, Historia persecutionis Africanae provinciae tempore Geiserici et Hunerici regum Wandalorum, I, 2 (2), ed. K. Vössing, Victor von Vita. Kirchenkampf und Verfolgung unter den Vandalen in Africa, Darmstadt 2011 (Qui reperti sunt senes, iuvenes, parvuli, servi vel domini, octoginta milia numerati. Quae opinio divulgata, usque in hodiernum a nescientibus armatorum tantus numerus aestimatur, cum sit nunc exiguus et infirmus); oraz: Procopius Caesariensis, Bella

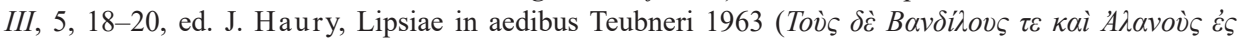

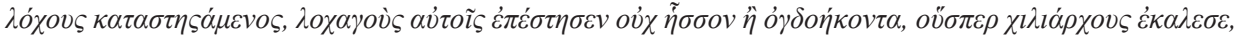

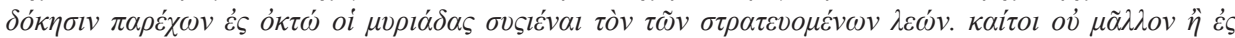

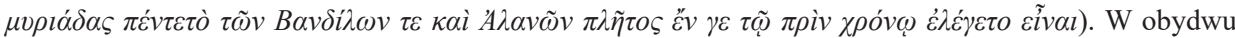
przekazach podana jest liczba 80000 odnosząca się raczej do całego ludu niż do wojowników. Rzuca się też w oczy, że obydwaj autorzy uważają ją za zawyżoną i rozpowszechnianą raczej w celu stworzenia przekonania, że taka jest siła Wandalów, podczas gdy w istocie była ona mniejsza (choć Procopius Caesariensis, Bella III, 5, 20, twierdził, że ogólna liczba mieszkańców królestwa zwiększała się z latami przez przyrost naturalny i przyłączenie się ,innych barbarzyńców”). Według dość powszechnie przyjmowanych szacunków wojowników Gejzeryka mogło być ok. 15 000, a więc nie była to masa umożliwiająca pozostawianie licznych garnizonów w każdej zajętej miejscowości. W najnowszych opracowaniach znaleźć można podobne poglądy - zob. H. Castritius, Die Vandalen. Etappen einer Spurensuche, Stuttgart 2007, s. 80; A. Merrills, R. Miles, The Vandals, Chichester 2010, s. 54; J. Strzelczyk, Wandalowie i ich afrykańskie państwo, Warszawa 2005, s. 125 n.; K. Vössing, Das Königreich der Vandalen. Geiserichs Herrschaft und das Imperium Romanum, Darmstadt 2014, s. 39 (szacuje ich liczbę na 10 000-20 000); Y. Modéran, Les vandales et l'Empire Romain, Arles 2014, s. 96 nn.; M. Wilczyński, Gejzeryk i „czwarta wojna punicka”, Oświęcim 2016, s. 100 n.; R. Steinacher, op. cit., s. $94 \mathrm{nn}$. Jak licznymi wojskami dysponował Bonifacjusz, trudno określić. Notitia Dignitatum Oc. VII, 140-152, 180-198 i XXV, 20-30, wymienia na etacie komesa Afryki: 3 legie pałacowe, 1 auxilium pałacowe, 8 legionów liniowych, 19 vexilationes liniowych i 16 jednostek wojsk pogranicznych. Do tego dodać można jeszcze nieznaną liczbę buccellarii Bonifacjusza i gockie oddziały Sigiswulta. Przyjmując, że zachowano pełne etaty, daje to nieco większą liczbę żołnierzy niż Gejzerykowe ok. 15 000, ale nie wiadomo, czy po buncie Herakliana w 423 r. i samego Bonifacjusza tuż przed inwazją Wandalów dane te zachowały aktualność. Zapewne nie. Bardzo sceptycznie siłę armii rzymskiej w Afryce ocenia Y. Modéran, op. cit., s. 103 nn. (Un armée Fantôme?); podobnie H. Castritius, op. cit., s. 83, który szacuje liczebność jednostek rzymskich na najwyżej 10 000. Zob. też: M. Wilczyński, Gejzeryk..., s. 99. R. Steinacher (op. cit., s. 84) potwierdza, że przy pełnych stanach dane z Notitia Dignitatum pozwalają szacować wojska rzymskiej Afryki na 20 000-23 000, lecz realistycznie, podobnie jak H. Castritius, ocenia ich stan w 429 r. na 10 000. Bardzo źle ocenił wartość bojową afrykańskiej armii rzymskiej urodzony w Tunisie Y. Le Bohec, Das römische Heer in der Späten Kaiserzeit, übersetzt von A. und G. Kolde, Stuttgart 2010, s. 257 n.

3 Pod koniec oblężenia wojskom królewskim mimo podjętych działań zagroził głód (Procopius Caesariensis, Bella III, 3, 34). 
z Konstantynopola Gejzeryk założył swoją kwaterę główną w Hippo Regius ${ }^{4}$. Nadal trudno mówić o źródłowym poświadczeniu istnienia jakiejkolwiek formy garnizonu, poza głównym obozem królewskim. Rozstrzygająca okazała się sprawa zaopatrzenia, której na razie bez nadziałów ziemi nie można było ostatecznie rozwiązać. Rabunkowe rajdy na tereny bogatych w zboże, a leżących poza zasięgiem Gejzeryka prowincji Proconsularis czy Byzacena świadczą o ciągle dominującej metodzie doraźnego uzupełniania zaopatrzenia armii. Wprawdzie po zawarciu pokoju w 435 roku Wandalowie uzyskali część Numidii i Mauretanii Sitifeńskiej, ale te zdobycze nie pozwalały na całkowite zerwanie zależności od cesarstwa i nie satysfakcjonowały Gejzeryka. Cztery lata później (19 października 439 r.) zajął zdradziecko, bez walki, Kartaginę wraz z portem i znajdującymi się w nim okrętami oraz upragnione ziemie żyznych prowincji, otaczające stolicę rzymskiej Afryki.

Od tego momentu król Gejzeryk przystąpił do intensywnej budowy struktury obronnej zdobytych dziedzin, łącząc w jedno zapewnienie wojownikom stałych źródeł aprowizacji i konieczność zachowania zdolności przeprowadzenia sprawnej mobilizacji na wypadek wojny. Król Wandalów wybrał rozwiązanie w danym momencie optymalne, tworząc „garnizon rozproszony”. Służyło temu osiedlenie wojowników królewskich na ziemiach opasujących wielokilometrowym kręgiem Kartaginę. Aby to osiągnąć, należało przede wszystkim wywłaszczyć i częściowo wysiedlić rzymskich posiadaczy ziemskich, gospodarzących na najlepszych i żyznych ziemiach w pobliżu stolicy. Podjęcie tych działań było możliwe dopiero po zajęciu Kartaginy ${ }^{5}$, ponieważ z jednej strony król kontrolował tereny zamierzonych wysiedleń, a z drugiej - przewidując co najmniej kilkuletnie walki z cesarstwem - musiał wśród swoich wojowników rozbudzić silną motywację do walki. Jak wiadomo, najtwardziej broni się domowego progu, a więc należało jak najszybciej Wandalom progi owe podarować . Poruszający opis niedoli wygnanych i zdeklasowanych rzymskich possessores przekazał Prokopiusz z Cezarei. Zapewne z pewną przesadą relacjonował, że najbardziej znaczących posiadaczy ziemskich wraz z ich majątkami król darował swoim synom Hunerykowi i Genzonowi lub zatrzymał dla siebie ${ }^{7}$. W ten sposób położył podwaliny pod domenę królewską, mającą stanowić ekonomiczną podstawę panowania rodu Asdingów. „Pozostałych Libijczyków” król wywłaszczył, konfiskując najlepsze ziemie, które do czasów Prokopiusza znane były jako „majątki wandal-

4 Prosper Tiro w: Chronik, 1321, ediert, übersetzt und kommentiert von M. Becker, J.-M. Kötter, Paderborn 2016, wyraźnie poświadcza, że pokój Trygecjusza w 435 r. zawarto w Hipponie, a zatem tam właśnie była siedziba Gejzeryka aż do 439 r.

5 R. Steinacher, op. cit., s. 151, uważa nawet, że wysiedlenia i przyznanie majątków wojownikom nastąpiły dopiero po traktacie pokojowym z $442 \mathrm{r}$.

${ }^{6}$ I to podarować jako własność dziedziczną - Victor Vitensis, Historia persecutionis..., I, 4 (13) - ...exercitui vero Zeugitanam vel Proconsularem funiculo hereditatis divisit... Status włości dziedzicznych utrzymywał się tak silnie, że po podboju afrykańskiego królestwa Wandalów przez Belizariusza żołnierze rzymscy, którzy poślubili kobiety wandalskie, żądali ich dziedzicznych majątków, a wobec wcielania tych ziem do domeny skarbu cesarskiego podnieśli bunt - Procopius Caesariensis, Bella IV , 14, 8-11. Zob. też: G. Halsall, Barbarian Migrations and the Roman West, New York 2007, s. 445; R. Steinacher, op. cit., s. 160 n.

7 Procopius Caesariensis, Bella III, 5, 11. 


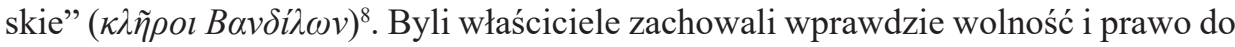
emigracji, lecz przyszło im żyć w wielkiej biedzie ${ }^{9}$. Kilka linijek dalej poinformował, że wywłaszczenia nie dotknęły wszystkich ,pozostałych Libijczyków”, ponieważ ziemie gorszej jakości (zapewne położone dalej od stolicy) pozostawił ich właścicielom, lecz nałożył na nie ciężary podatkowe, a dodatkowe szykany i konfiskaty mienia czyniły życie mieszkańców tych peryferyjnych terenów bardzo trudnym.

Wydzielenie sortes Wandalorum było posunięciem zarówno ekonomicznym, jak i militarnym, ale też administracyjnym i prestiżowo-propagandowym. Król zgodnie z germańskimi zasadami zapewniał wojownikom utrzymanie i obfitą konsumpcję. Oprócz ziemi otrzymali oni zapewne także kolonów mających ją uprawiać. Ekonomicznie stawiało to prostego wojownika na poziomie rzymskiego posiadacza niewielkiego majątku rolnego. Przy dość dobrej bazie źródłowej nie znajdujemy potwierdzenia dodatkowego finansowania wojowników z przychodów uzyskiwanych przez Gejzeryka z podatków od ludności rzymskiej. Zapewne nie było takiej potrzeby. Główną podstawę utrzymania wojowników i ich rodzin stanowiły wolne od podatków majątki ziemskie. Ich posiadanie obligowało wojowników do służby wojskowej zarówno w obronie królestwa, jak i w ramach realizowania agresywnej polityki królewskiej, na przykład do udziału w rajdach królewskiej floty, które terroryzowały obie części Cesarstwa Rzymskiego. Oczywiście nie można wykluczyć okazjonalnego rozdawnictwa nagród dla zasłużonych wojowników, ale i o tym źródła raczej nie wspominają. Zamiast takiej formy motywacji Gejzeryk zapewniał swoim wojom możliwość pozyskiwania dodatkowych dochodów z łupów wojennych. Niezależnie od tego, jak dzielono zdobyte dobra, kosztowności i jeńców, to określony zwyczajowo udział wojowników w łupach był gwarantowany jako część należnych przychodów. Wiadomo, że prawo do zdobyczy było absolutnie nienaruszalne i nawet skłonny do despotycznych posunięć król Gejzeryk nie ważył się go naruszać. W czasie rokowań z posłem cesarskim Sewerusem Gejzeryk chciał pozyskać konstantynopolitańskiego dyplomatę i przekazać bardzo bogate dary. Sewerus, odmawiając, podziękował za dary dla siebie i prosił o możliwość zwolnienia lub wykupu jeńców rzymskich porwanych w czasie wypraw korsarskich lub pojmanych w wojnie 468

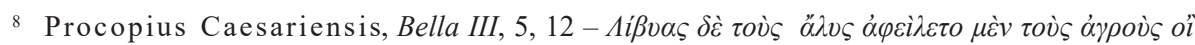

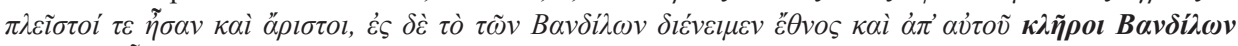

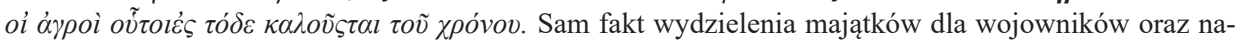
dania im nazwy podobnej do przekazanej przez Prokopiusza potwierdził Wiktor z Wity. Cytuje on edykt króla Huneryka, zabraniający kultu katolickiego na terenach majątków wandalskich (sortes Wandalorum) - Victor Vitensis, Historia persecutionis..., IV, 2 - ...ut in sortibus Wandalorum nullos conventus omousiani sacerdotes adsumerent. H. Wolfram jest zdania, że nadania ziemi dla wojowników odbyły się częściowo kosztem zarekwirowanych dóbr domeny cesarskiej, jak też wysiedleń indywidualnych prywatnych posiadaczy ziemskich. Zob. idem, Gotische Studien. Volk und Herrschaft im frühen Mittelalter, München 2005, s. 200-201. Zob. też: K. Vössing, Das Königreich der Vandalen..., s. 75 n.; A. Merrills, R. Miles, op. cit., s. 167 n.; Y. Modéran, op. cit., s. 155 n. R. Steinacher (op. cit., s. 151 n. oraz 162 n.) podkreśla wieloznaczność słowa sors i wskazuje na prawne i organizacyjne różnice między sortes u Wizygotów, Burgundów i Wandalów.

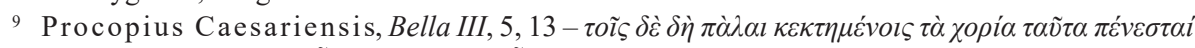

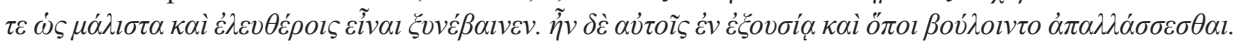


roku. Król natychmiast zadeklarował bezpłatny zwrot jeńców będących w jego i jego synów posiadaniu, zastrzegł jednak, że z możnymi plemienia i wojownikami poseł cesarski musi rokować w sprawie odkupu na zwykłych zasadach handlowych ${ }^{10}$. Łup wojenny, a szczególnie cenne ręce do pracy w gospodarstwach wandalskich posiadaczy, był częścią dochodu oraz nagrody za męstwo i nawet król nie mógł naruszać praw prywatnej własności wojowników.

Dochody z majątków i innych źródeł zapewniały żołnierzom nie tylko utrzymanie, ale także przygotowanie niezbędnego uzbrojenia osobistego. Równocześnie zachowywano nadal dyscyplinę wojskową i administrację opartą na prerogatywach dowódczych tysięczników. Tysięcznicy stanowili kadrę dowódczą, ale również ogniwo pośrednie między administracją dworską a ludem, pełniąc funkcje administracyjne niższego szczebla $^{11}$. Zapewne odpowiadali także za stan uzbrojenia podległych sobie wojowników, organizując nawet fachowe naprawy i konserwację broni. Wiktor z Wity zaświadcza, że w majątku wandalskiego millenariusa, którego imienia nie podaje, zatrudniony był zbrojmistrz Martynian ${ }^{12}$. Możliwe, że nie był to wyjątek, choć nie ma podstaw do twierdzenia, że każdy millenarius zbrojmistrza posiadał.

Trudno ustalić, jak duży liczebnie i terytorialnie był wandalski ,garnizon rozproszony". Tylko raz Wandalowie zostali zliczeni przed wyprawą do Afryki ${ }^{13}$, a źródła z późniejszego okresu tylko dwa razy informują o liczebności jednostek wandalskich, przy okazji relacji działań w 533 roku. Wyruszający na Sardynię przeciw buntowi Godasa brat króla Gelimera Tzazon miał 5000 ludzi i 120 okrętów, a strzegący flanki armii wandalskiej Gibamund dowodził oddziałem 2000 Wandalów $^{14}$. Z pozostałymi siłami Gelimer stanowił jeszcze zagrożenie dla rzymskiego desantu pod wodzą Belizariusza i jedynie brakowi dyscypliny i koordynacji działań oddziałów królewskich Rzymianie zawdzięczali zwycięstwo pod Decimum. Można więc mówić o kilkunastu tysiącach zobowiązanych do mobilizacji, a siły te wzmacniały jeszcze sojusznicze oddziały Maurów. Granice sorters Wandalorum trudno określić. Znajdowały się, jak już powiedziano, na obszarze prowincji Proconsularis i Byzacena, a logiczne - gdy ma się na względzie mobilizację - jest lokowanie ich na terenach otaczających stolicę ${ }^{15}$. Jedyna odległość podana w źródłach to oddalenie pałacu królewskiego

10 R.C. Malchus-Blockley, The Fragmentary Classicising Historians of the Later Roman Empire. Eumapius, Olympiodorus, Priscus and Malchus, text, translation and historiographical notes, ARCA

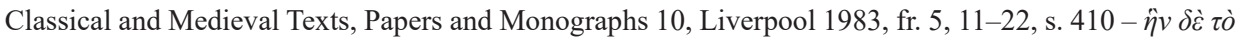

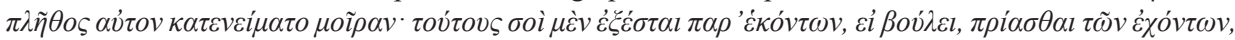

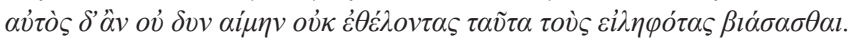

11 D. Claude, Der Millenarius [w:] Anerkennung und Integration..., s. 19; Ch. Courtois, Les Vandales et l'Afrique, Paris 1955, s. 259; G. Maier, Amtsträger und Herrscher in der Romania Gothica. Vergleichende Untersuchungen zu den Institutionen der ostgermanischen Völkerwanderungsreiche, Historia Einzelschriften - 181, Stuttgart 2005, s. 225 n.; R. Stein acher, op. cit., s. 163 n.

12 Victor Vitensis, Historia persecutionis..., I, 10 (30).

13 Zob. przyp. 2.

14 Procopius Caesariensis, Bella III, 11, 23 i 18, 12.

15 A. Merrils (Kingdom of North Africa [w:] The Age of Attila, ed. M. Maas, New York, 2015, s. 267) skłonny był ograniczać osadnictwo wojowników do terenu prowincji Proconsularis: „Our sources 
w Grasse, leżącego 350 stadiów, czyli około $65 \mathrm{~km}$, na południe od Kartaginy ${ }^{16}$. Pamiętać jednak należy, że mowa tu o pałacu królewskim, a nie majątkach wojowników. Nie można na pewno mówić o jednym, jednolicie zasiedlonym obszarze ${ }^{17}$, ponieważ na tym samym terenie były majątki domeny królewskiej i prywatne włości rodziny Asdingów. Wydaje się, że istniało więcej obszarów osadnictwa wojowników - stąd propozycja, by mówić o ,garnizonach rozproszonych”, a nie o garnizonie. Niestety ani źródła pisane, ani archeologia nie mogą pomóc w dokładniejszym określeniu obszaru osadnictwa wojskowego Wandalów, tym bardziej że następowało też obustronne przejmowanie ubioru i rytuałów pogrzebowych, więc siedziby i groby Wandalów i Rzymian afrykańskich nie zawsze można od siebie odróżnić ${ }^{18}$.

Administracyjno-wojskowa struktura wandalskiego „garnizonu rozproszonego" funkcjonowała na podobnych zasadach jak w zwykłym garnizonie, lecz na większym obszarze. Dbano nawet o kult religijny, czy raczej o jego czystość, surowo tępiąc wszelką aktywność Kościoła katolickiego w sortes Wandalorum, które miały pozostać wandalskie i ariańskie ${ }^{19}$. Dobra Kościoła na terenach sortes zostały skonfiskowane i prawdopodobnie przekazane klerowi ariańskiemu ${ }^{20}$, zapewniającemu ,garnizonom rozproszonym" opiekę duszpasterską. Także na terenach, gdzie zamieszkiwali wspólnie Wandalowie i Rzymianie (np. w miastach) i gdzie znajdowały się kościoły katolickie, nawet kazania w nich głoszone poddane były surowej cenzurze ${ }^{21}$.

are clear that the 'Vandal estates' were limited to Africa Proconsularis - that is the territory immediately surrounding Carthage".

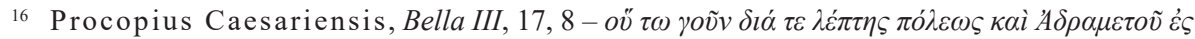

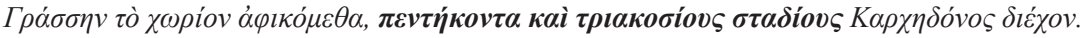

17 R. Steinacher, op. cit., s. 163.

18 Zob. Ph. von Rumme1, Where Have All the Vandals Gone? Migration, Ansiedlung und Identität der Vandalen im Spiegel archäologischer Quellen aus Nordafrika [w:] Das Reich der Vandalen und seine (Vor-) Geschichten, Hrsg. G.M. von Berndt, R. Steinacher, Wien 2008, s. 151-182; Ch. Eger, Vandalisches Trachtzubehör? Zu Herrkunft, Verbreitung und Kontext ausgewählter Fibeltypen in Nordafrika [w:] Das Reich der Vandalen..., s. 183-196 (na s. 191 podane są jednak pojedyncze miejsca znalezienia typowych dla germańskiego kręgu kultur naddunajskich fibul kuszowatych, mogących wskazywać na osadnictwo wandalskie).

19 Dobrym przykładem takiej działalności oraz dowodem sprawności mobilizacji niewielkich sił na szczeblu lokalnym jest działanie ariańskiego kapłana Anduita, który na wieść, że katolicy otworzyli w miejscowości Regia, znajdującej się na terenie sortes Wandalorum, zamknięty kościół, by świętować Wielkanoc, zebrał sprawnie oddział Wandalów, zbrojnie naszedł kościół i dokonał masakry wiernych Victor Vitensis, Historia persecutionis..., I, 13 (41) - Statim quidam presbyter eorum (Arianorum - MW), Anduit nomine, congregata secum armatorum manu ad expugnandum turbam accenditur innocentum. Introerunt evaginatis spatis, arma corripiunt; alii quoque tecta conscendunt et per fenestras ecclesiae sagittas spargunt. Et tunc forte audiente et canente populo dei lector unus pulpito sistens alleluiaticummelos canebat; quo tempore sagitta in gutture iaculatus, cadendede manibus codice, martuus post cecidit ipse. $\mathrm{Z}$ opisu wynika, że nie chodzi o doraźnie zebraną hałastrę chłopów z najbliższego majątku, ale o szybko zgrupowany oddział wojowników zbrojnych w miecze i łuki i sprawnie się nimi posługujących. Wszystko przebiegło w krótkim czasie, ponieważ podczas ostrzału zginął trafiony w gardło lektor odśpiewujący „Alleluja” przed czytaniem Ewangelii, a więc od włamania się katolików do zamkniętego kościoła do chwili ataku zebranego przez Andiuta oddziału nie upłynęło wiele czasu.

20 R. Steinacher, op. cit., s. 153.

21 Victor Vitensis, Historia persecutionis..., I, 7 (22). 
Tereny zajmowane przez „garnizony rozproszone” stanowiły bazę mobilizacyjną umożliwiającą dzięki zwartemu osadnictwu i wojskowej strukturze zarządzania dość szybkie osiąganie stanu gotowości bojowej przez znaczącą liczebnie armię. Dowodem na to jest błyskawiczna mobilizacja sił wandalskich wiosną 455 roku. 16 marca zamordowano w Rzymie cesarza Walentyniana III. By wieść dotarła do Kartaginy na początku sezonu żeglugowego, też trzeba było trochę czasu. Gejzeryk stanął pod murami Rzymu dokładnie 2 czerwca. Mobilizacja, zaopatrzenie, zaokrętowanie i przeprawa dużej liczby jednostek wandalskich i pomocniczych wojsk mauretańskich zajęła nieco ponad dwa miesiące, co świadczy o niezwykle sprawnym działaniu królewskiego ,garnizonu rozproszonego”.

Prócz wojowników z sortes Wandalorum istniały też w królestwie zupełnie normalne garnizony wojskowe. W samej Kartaginie stacjonowała straż przyboczna kró$\mathrm{la}^{22}$ oraz załoga portu wojennego, w tym obsada królewskich okrętów, zapewniająca stałą gotowość floty korsarskiej. O uzbrojenie i utrzymanie tych jednostek troszczył się bezpośrednio sam władca ${ }^{23}$. Istniały wysunięte placówki wartownicze i pocztowe zapewniające kontrolę nad pograniczem, ale silnych garnizonów wandalskich w innych miastach Afryki rzymskiej nie było, tym bardziej że na rozkaz Gejzeryka ich umocnienia zostały rozebrane lub uszkodzone. Poza Afryką niewielkie garnizony wandalskie, zapewniające bezpieczną żeglugę i naprawy okrętów królewskich, istniały na Sardynii (Caralis), Balearach i Sycylii (Lilybeum).

Przykład królestwa Wandalów najlepiej ilustruje funkcjonowanie ,garnizonu rozproszonego", ale podobne, choć nie identyczne formy osadnictwa połączonego z funkcjami militarnymi i mobilizacyjnymi odnaleźć można także w innych królestwach „barbarzyńskich” V i VI wieku. Ciekawych przykładów z italskiego królestwa Ostrogotów dostarczają dokumenty zebrane w Variae Aureliusza Kasjodora. W porównaniu z królestwem Wandalów osadnictwo wojowników ostrogockich w Italii nie skupiło się na jednym wydzielonym obszarze. Gockie garnizony występowały w wielu miastach Italii, a nie tylko wokół stołecznej Rawenny. Źródłem utrzymania wojowników były częściowo dochody z posiadanych majątków (w przeciwieństwie do sortes Wandalorum podlegających obowiązkowi podatkowemu $)^{24}$,

22 Victor Vitensis wspomina o próbie przebłagania Gejzeryka przez delegację kleru kartagińskiego, chcącego złagodzenia represji antykatolickich. Zatrzymali oni króla w czasie przejażdżki po wybrzeżu maksulitańskim, lecz ten rozjuszony chciał wydać rozkaz, by potopiono błagalników w morzu. Trudno sobie wyobrazić, aby zabijać biskupów mieli dostojnicy królewscy (którzy zresztą powstrzymali władcę przed tym czynem). Rozkaz skierowany był zapewne do towarzyszących królowi gwardzistów, stacjonujących na stałe przy siedzibie monarchy. Zob. Victor Vitensis, Historia persecutionis ..., I, 5 (18).

${ }_{23}$ Prokopiusz z Cezarei przy okazji opisu mało wiarygodnej eskapady cesarza Majoriana, który miał udawać w Kartaginie własnego posła, potwierdza istnienie w stolicy dużego arsenału - Procopius Ca-

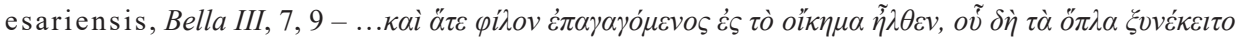

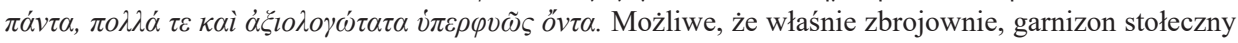
i garnizon portowy finansowano z przychodów fiskalnych.

24 Cassiodorus Aurelius, Variae IV, 14, ed. Th. Mommsen, Monumenta Germaniae Historica Auctores Antiquissimi XI (1894), s. 1-108. W liście skierowanym do sajona Gezyli król Teodoryk Wielki nakazuje, by Gezyla przymusił Gotów posiadających majątki w Picenum i Tusciach do zapłacenia należnych podatków pod groźbą konfiskaty posiadanych nieruchomości. Ciekawa uwaga - qui enim debent ad fiscum celerius esse devoti, nisi qui capiuntcommoda donativi, quando amplius de nostra humanitate 
ale znaczna ich liczba utrzymywała się ze środków rozdzielanych w określonych terminach przez administrację królewską jako stipendium, annona czy donativum ${ }^{25}$. W posiadanie majątków rolnych wchodzili Goci bądź dzięki nadaniom królewskim, bądź też nabywając ziemię ze środków, które pozostawały wolne po pokryciu kosztów utrzymania samych wojowników i ich rodzin ${ }^{26}$. Zgodnie z podstawową zasadą polityki Teodoryka Wielkiego, że jedynym wojskiem broniącym Italii jest exercitus Gothorum (czy też może poprawniej exercitus foederatorum ${ }^{27}$ ), niemożliwe było skoncentrowanie wszystkich sił militarnych na jednym obszarze. Wojownicy goccy osiedlali się $\mathrm{w}$ okolicach różnych miast italskich lub bezpośrednio w miastach $^{28}$. W edyktach królewskich redagowanych w podniosłym stylu przez Aureliusza Kasjodora znajdujemy wezwania do wspólnej pokojowej koegzystencji Gotów i Rzymian w miastach Italiii ${ }^{29}$. Szczególnie ostro piętnowano wszelkie rabunki, a nawet przypadkowe szkody wyrządzone przez wojowników miejscowej ludności ${ }^{30}$. Z pism Teodoryka Wielkiego kierowanych do Rzymian i Gotów, wzywających do

recipiunt quam stipendii iure praestetur? - być może sugeruje, że goccy osadnicy z Picenum i Tuscji prócz dochodów z posiadanej ziemi otrzymują też zwyczajowe stipendia wypłacane wojsku z jednej trzeciej wpływów podatkowych, ale tekst nie jest do końca jednoznaczny.

${ }_{25}$ Cassidorus Aurelius, Variae V, 26 i 27. Teodoryk w piśmie do Gotów z Piceno i Sannio (26) wzywa ich do przybycia 6 VI do Rawenny w celu odebrania królewskich darów, a w piśmie do sajona Guguina (27) przypomina, że tysięcznicy z Piceno i Sannio winni zadbać o wysunięcie zasłużonych wojowników do nagród. H. Wolfram (Die Goten. Von den Anfängen bis zur Mitte des sechsten Jahrhunderts. Entwurf einer historischen Ethnographie, Aufl. 3, München-Wien 1990, s. 299) uważa, że na dochody wojowników w gockich garnizonach składało się kilka komponentów - po pierwsze, sors lub tertia, czyli utrzymanie i środki pieniężne wypłacane z trzeciej części podatku gruntowego, ściąganego przez kuriałów; po drugie, żołd (stipendium, annona) wypłacany przebywającym w garnizonach lub aktualnie czynnym wojskowo Gotom; po trzecie, wypłacane w przypadkach szczególnych nagrody i dary (donativa). Wszystkie te dochody - w przeciwieństwie do dochodów z majątków ziemskich - nie były opodatkowane (zob. H. Wolfram, Gotische Studien..., s. 195).

26 H. Wolfram, Die Goten..., s. 298.

27 Mimo że lwią część wojsk Teodoryka Wielkiego stanowili Ostrogoci, to nie była to jedyna grupa plemienna pod jego rozkazami. Wiadomo o Herulach, którym urzędnicy z Pawii mieli zapewnić statek i żywność na pięć dni w celu odbycia podróży do Rawenny (Cassiodorus Aurelius, Variae IV, 45). Sajon Weran został przez Teodoryka Wielkiego zobowiązany do zapewnienia aprowizacji maszerującym do Galii na rozkaz króla oddziałom Gepidów, a sami Gepidowie osobnym pismem upomniani, by żywność kupowali, a nie rabowali (Cassiodorus Aurelius, Variae V, 10 i 11).

28 H. Wolfram (Die Goten ..., s. 297) wskazuje jako najważniejsze obszary osadnictwa gockiego wśród ludności rzymskiej dzisiejszą Lombardię, jak też dawne Venetię, Tuscję oraz ląd stały i wyspy w Dalmacji.

29 Cassiodorus Aurelius, Variae, VII 3, 3 (Formula comitivae Gothorum - vos autem, Romani, magno studio Gothos diligere debetis, qui et in pace numerosos vobispopulos faciunt et universam rem publicam per bela defendunt); także VII 3, 2 (Sic pace communi utraeque nationes divinitate propita dulci otio perfruatur); również Variae I, 17, 1; III, 48, 1 i 5; V, 23.

${ }^{30}$ Cassiodorus Aurelius, Variae II, 8 (Teodoryk prosi biskupa Sewera o rozdzielenie odszkodowań za szkody poczynione w czasie przemarszu wojsk); IV, 13; IV, 36 (Teodoryk zwalnia mieszkańców prowincji Alp Kottyjskich z podatku w ramach rekompensaty za straty wywołane przemarszem wojsk); VI 22,3; VI, 26, 2 (Teodoryk zabrania Gotom zmierzającym do Rawenny po dary królewskie niszczenia pól i grabieży); X, 18, 2 (Theodahad nakazuje wojsku posłanemu do Rzymu płacić za żywność zgodnie $\mathrm{z}$ obowiązującymi cenami). 
koegzystencji w miastach i wspólnych wysiłków dla publicznego dobra, wynika, że Goci przynajmniej w części garnizonów nie byli skoszarowani, lecz zamieszkiwali w miastach i ich okolicach. Na wezwanie królewskie stawali zbrojnie i uczestniczyli w wyprawach poza Italię. Nieustanna gotowość do walki i doskonalenie umiejętności wojskowych było obowiązkiem każdego Gota już od młodych lat ${ }^{31}$. Choć królestwo Ostrogotów nie dysponowało tak groźną i silną flotą wojenną jak królestwo Wandalów, to jednak istniały jednostki, które można uznać za garnizony nabrzeżne, dbające o zapewnienie transportu statkami. Za rozbudowę floty odpowiadał między innymi prefekt pretorium Abudancjusz, który przygotowywał też żeglarzy i wioślarzy do służby. W pozyskiwaniu drewna pomagał mu sajon Aliulf, a w werbunku i dyslokacji żeglarzy - sajon Gudinand ${ }^{32}$. Ostrogoci tworzyli zatem garnizony miejskie, pograniczne i ,garnizony rozproszone” jako tereny osadnictwa wojskowego i okręgi mobilizacyjne, ale w większym stopniu niż Wandalowie koegzystowali z Rzymianami w miastach oraz byli wynagradzani za służbę na innych zasadach.

Mniej bogatą bazą źródłową dysponujemy do poznania organizacji garnizonów wizygockich, swebskich i burgundzkich. W przypadku Wizygotów o początku stałych garnizonów można mówić od momentu stałego osiedlenia się plemienia w południowej Galii po przekazaniu prowincji Akwitanii pod osadnictwo wojownikom króla Walii. Sam Walia nie dożył momentu zasiedlenia nowych ziem, zadanie to przypadło jego następcy Teodorykowi $\mathrm{I}^{33}$. Niestety źródła nie dają możliwości stwierdzenia, czy w wizygockiej Galii istniały formy podobne do wandalskiego ,garnizonu rozproszonego". Dawne teorie o przydziale jednej trzeciej ziemi implikowałyby takie rozwiązanie, lecz dziś powszechnie przyjmuje się, że nie chodziło o ziemię, ale o dochody z podatków, których w Galii na utrzymanie wojska gockiego przeznaczano być może nawet więcej niż jedną trzecią ${ }^{34}$. Zapewne punktami koncentracji wojsk były ważne strategicznie punkty, przede wszystkim stołeczna Tuluza. Zarówno w samym mieście, jak i jego okolicy stacjonowały oddziały pod bezpośrednim dowództwem króla, a w samym mieście garnizon miała gwardia królewska ${ }^{35}$. Istniały też majątki gockie

31 Cassiodorus Aurelius, Variae I, 24. Król Teodoryk wzywa wojowników, by pod wodzą sajona Nanduina wyruszyli na wyprawę wojenną, która będzie też okazją do hartowania cnót młodzieży (I, 24, 3 - Producite iuvenes vestros in Martiam disciplinam; sub vobis videant, quod posteris referre contendant).

32 Cassiodorus Aurelius, Variae V, 17 i 19 oraz 20. O uzupełnieniach (za 21 wioślarzy zmarłych w wyniku wypadku), których miał dokonać Benenatus, dowiadujemy się z Variae IV, 15.

33 O osadnictwie Wizygotów w Akwitanii w najnowszej literaturze: G. Kampers, Geschichte der Westgoten, Paderborn-München-Wien-Zürich 2008, s. 121 n.; H. Wolfram, Gotische Studien..., s. 187 n., Ch. Delaplace, La fin del'Empire romain d'Occident. Rome et les Wisigoths de 382 à 531, Rennes Cedex 2015, s. 185 nn.

${ }^{34}$ H. Wolfram (Die Goten..., s. 227) sugeruje, że w przypadku podatku pogłównego na utrzymanie wojska barbarzyńców przeznaczano trzecią cześć, lecz z annony pobierano dwie trzecie. Wynikało to zapewne z tego, że podczas gdy Odoaker i Teodoryk Wielki zachowali wyższe szczeble administracji rzymskiej i podział przeznaczenia dochodów na trzy części - na wojsko, na urzędy centralne i na urzędy municypialne, to u Wizygotów w Galii druga z wymienionych pozycji wydatków właściwie nie istniała i rzymska administracja działała wyłącznie na poziomie municypiów.

35 Istnienie takiej gwardii potwierdza Sidonius Apollinaris, Epistulae I, 2, ed. Ch. Luetjohann, Monumenta Germaniae Historica Auctores Antiquissimi VIII (1887); zob. też: M. Wilczyński, 
posiadane czy to z nadania, czy na podstawie zakupu, które mogły być miejscem stacjonowania wojowników. Podział sił zbrojnych Wizygotów na jednostki dowodzone przez tysięczników (biufaps - thiufadus) może sugerować, że musiały istnieć rejony osiedlenia i mobilizacji podległych im wojowników, a jednak ani źródła pisane, ani archeologia, ani badania toponimów nie pozwalają na pewne potwierdzenie ich istnienia i lokalizacji ${ }^{36}$. Dodatkowo sytuację komplikuje niejednolity charakter armii Wizygotów, w skład której oprócz samych Gotów wchodzili inni barbarzyńcy, lokalni laeti i gentiles oraz znaczne oddziały prywatne galijskich, a potem i hiszpańskich possessores ${ }^{37}$.

Jeszcze mniej można powiedzieć o królestwie Swebów. Nie wiadomo w ogóle, czy osiedlali się jako foederatii, jak Goci, czy też raczej, co bardziej prawdopodobne, utrzymali niezależność jak Wandalowie. Źródła mówią raczej o długotrwałej fazie rabowania majątków rzymskich posiadaczy w Galaecji ${ }^{38}$. Obszary koncentracji wojowników wyznaczały miejsca rezydowania króla. Od czasów Hermeryka (panował w latach 409-438/441) centrum koncentracji była Braga i możliwe, że wokół niej powstało coś podobnego do wandalskich „garnizonów rozproszonych”39. W późniejszym okresie podobne zgrupowania wojsk powstały wokół zajętej przez króla Rechilę Méridy. Kierunki uderzeń Teodoryka II wizygockiego w 456 roku (Braga, Astorga, Mérida) mogą sugerować, że trzecim okręgiem mobilizacyjnym była Astorga ${ }^{40}$. Możliwe, że niewielki garnizon przybrzeżny znajdował się w Porto, dokąd po klęsce w 456 roku usiłował zbiec król Rechiar ${ }^{41}$. W VI wieku królestwo zostało podzielone na okręgi (parrocias) zarządzane w imieniu króla przez komesów ${ }^{42}$. Można jedynie przypuszczać, że byli oni też odpowiedzialni za przygotowanie wojskowe i gotowość mobilizacyjną osiedlonych w ich okręgach Swebów ${ }^{43}$, ale o tym, czy i jakie garnizony tam się znajdowały, nie można nic powiedzieć.

Exercitus Barbarorum. Organizacja i działania wojsk ludów germańskich osiadlych w Vi VI wieku w basenie Morza Śródziemnego, „Vox Patrum” 35 (2015), t. 63, s. 299.

36 H. Wolfram, Die Goten..., s. 229 n. (na podstawie wcześniejszych ustaleń E. Gamillschega, D. Claude i M. Rouche).

37 G. Maier, op. cit., s. 181 n.; M. Wilczyński, Exercitus barbarorum ..., s. 298 nn.

38 W okresie od 409 r. aż do pokoju 438 r., kiedy uregulowano stosunki pomiędzy Swebami a ludnością Galaecji (Hydatii Lemici, Continuatio chronicorum Hieronymianorum, 91, 96, 113, ed. T. Mommsen, Monumenta Germaniae Historica Auctores Antiquissimi XI (1893)).

39 Wskazuje na to m.in. kierunek ataku wojsk wandalskich króla Gunderyka w czasie konfliktu z Hermerykiem w 419 r. Podczas gdy część Wandalów blokowała Hermeryka w Górach Nerbasyjskich, druga ruszyła na Bragę, by przejąć stolicę i być może teren okolicznych „garnizonów rozproszonych” - Hydatii Lemici, Continuatio..., 73 i 74; zob. też: M. Wilczyński, Królestwo Swebów - regnum in etremitate mundi, Kraków 201, s. 90 n., idem, Gejzeryk..., s. 66 n., C. Torres Rodríguez, El reino de los suevos, Santiago de Compostella 1977, s. 61 n. O wczesnym osadnictwie wojskowym Swebów: P.C. Díaz, El reino suevo, Madrid 2011, s. 55 n.

40 Hydatii Lemici, Continuatio..., 173, 174, 186.

41 Ibidem, 175.

42 Divisio Theudemiri. Liber fidei snactae Bracarensis ecclesiae, 10, 11, ed. A. de Jesus da Costa, Braga 1965, s. 16-24.

43 M. Wilczyński, Exercitus barbarorum ..., s. 302. 
Osiedlenie Burgundów w Sapaudii przeprowadzone z woli Flawiusza Aecjusza to typowe osadnictwo foederatii. Źródła dwukrotnie mówią o podziale ziemi między barbarzyńcami a lokalną ludnością ${ }^{44}$. Ponieważ w 457 roku galijskie elity uznawały Burgundów za sojuszników, to osadnictwo burgundzkie postrzegano pozytywnie. Mimo dwukrotnej wzmianki o podziale ziemi między lokalnymi possessores a przybyłymi barbarzyńcami także w królestwie Burgundów nie ma dowodów na zasiedlenie jakiejś części ich królestwa według zasad znanych z wandalskiej Afryki. Być może wzmianki o podziale ziemi są śladem systemu „mieszanego”, czyli zapewniającego wojownikom utrzymanie w części z dóbr ziemskich, a w części z wpływów podatkowych regulowanych przez prawo. Jeżeli istniały jakieś formy garnizonów skupiających wojowników na konkretnym obszarze, to można się jedynie domyślać, że koncentrowały się wokół siedzib władców z rodu Gibikungów, a więc w okolicach Lyonu, Genewy, Vienne, a może i Dijon.

W niniejszym artykule - zgodnie z tytułem - przedstawiono jedynie kilka uwag o wandalskich ,garnizonach rozproszonych" w porównaniu z innymi królestwami barbarzyńskimi. Dokładne omówienie tematu wymaga raczej monografii. Oto kilka konkluzji w charakterze podsumowania.

Mimo popularności poszukiwania $\mathrm{w}$ badaniach historycznych stałych modeli funkcjonowania społeczeństw historycznych nie można dążyć do wtłoczenia w założony model wszystkich zjawisk, dlatego należy się opowiedzieć przeciw pełnemu przyjęciu modelu W. Goffarta i J. Durliata w odniesieniu do osadnictwa wojskowego Afryki wandalskiej. Bardziej słuszne wydają się wyważone i kompromisowe tezy D. Claude'a czy A. Merrilsa, dopuszczające zaopatrzenie wojowników wandalskich przez nadania ziemi i być może też z jakiejś formy dystrybucji przychodów fiskalnych.

Źródła jednoznacznie wskazują, że wojownicy wandalskich „garnizonów rozproszonych" żyli z otrzymanych nadziałów ziemi i pomnażali swój majątek przez łupy wojenne. Możliwe natomiast, że garnizony stałe i garnizony floty były finansowane z wpływów do skarbca królewskiego.

Przydzielając wojownikom majątki skonfiskowane ludności rzymskiej, Gejzeryk nie tylko rozwiązał problemy aprowizacji, ale także stworzył wokół Kartaginy strukturę zorganizowanego w jednostki podległe tysięcznikom i objętego ścisłą kontrolą „garnizonu rozproszonego" o niezwykle skutecznych mechanizmach szybkiej mobilizacji $\mathrm{w}$ razie potrzeby.

W porównaniu z innymi królestwami barbarzyńskimi tego okresu rozwiązanie wandalskie jest w pewnym sensie unikatowe. W państwach Gotów przeważał proponowany przez W. Goffarta i J. Durliata system utrzymywania armii barbarzyńskiej z trzeciej części dochodów podatkowych, co nie wykluczało posiadania przez

${ }^{44}$ Chronica Gallica a. CCCCLII et DXI, a. 443, ed. T. Mommsen, Monumenta Germaniae Historica Auctores Antiquissimi IX (1892) - Sapaudia Burgundionum reliquiis datur cum indigenis dividenda; Marii episcopi Aventicensis, Chronica a. CCCCLV-DLXXXI, a. 456, 2, ed. T. Mommsen, Monumenta Germaniae Historica Auctores Antiquissimi XI (1894) - Burgundiones partem Galiae occupaverunt terrasque cum Galli[i]s senatiribus diviserunt. 
Gotów majątków, lecz u Wandalów ta ostatnia forma dominowała, a ich majątki były, w przeciwieństwie do gockich, wolne od podatków.

Oryginalny charakter Gejzerykowego rozwiązania może wynikać z utrzymywanego przez króla Wandalów i Alanów statusu władcy suwerennego, co w końcu musiały uznać obie części Cesarstwa. Goci i Burgundowie byli przynajmniej formalnie foederatami, więc stosowano w stosunku do nich przyjęte metody finansowania z podatków.

Jedynie Swebowie być może przyjęli rozwiązania podobne do wandalskich, ale z powodu braku materiału źródłowego nie można tego w żaden sposób udowodnić.

Mając na uwadze asymilację ludności barbarzyńskiej z rzymską, należy stwierdzić, że wandalskie „garnizony rozproszone” w połączeniu z państwową polityką religijną działały kontrproduktywnie i spowalniały integrację, co w rezultacie osłabiło królestwo Wandalów. Inaczej proces asymilacji przebiegł w praktykujących inny model utrzymania armii królestwach gockich, a szczególnie w toledańskim państwie Wizygotów.

\section{BIBLIOGRAFIA}

\section{Źródła}

Cassiodorus Aurelius, Variae, ed. Th. Mommsen, Monumenta Germaniae Historica Auctores Antiquissimi XI (1894), s. 1-108.

Chronica Gallica a. CCCCLII et DXI., ed. T. Mommsen, Monumenta Germaniae Historica Auctores Antiquissimi IX (1892), s. 615-666.

Divisio Theudemiri. Liber fidei snactae Bracarensis ecclesiae, 10, 11, ed. A. de Jesus da Costa, Braga 1965, s. 16-24.

Hydatii Lemici, Continuatio chronicorum Hieronymianorum, ed. T. Mommsen, Monumenta Germaniae Historica Auctores Antiquissimi XI (1893), s. 1-36.

Malchus-Blockley R.C., The Fragmentary Classicising Historians of the Later Roman Empire. Eumapius, Olympiodorus, Priscus and Malchus, text, translation and historiographical notes, ARCA Classical and Medieval Texts, Papers and Monographs 10, Liverpool 1983, s. 402-462.

Marii episcopi Aventicensis, Chronica a. CCCCLV-DLXXXI, ed. T. Mommsen, Monumenta Germaniae Historica Auctores Antiquissimi XI (1894), s. 225-239.

Procopius Caesariensis, Bella I-IV., ed. J. Haury, Lipsiae in aedibus Teubneri 1963.

Prosper Tiro, Chronik, ediert, übersetzt und kommentiert von M. Becker und J.-M. Kötter, Paderborn 2016.

Sidonius Apollinaris, Epistulae, ed. Ch. Luetjohann, Monumenta Germaniae Historica Auctores Antiquissimi VIII (1887), s. 1-172.

Victor Vitensis, Historia persecutionis Africanae provinciae tempore Geiserici et Hunerici regum Wandalorum, ed. K. Vössing, Victor von Vita. Kirchenkampf und Verfolgung unter den Vandalen in Africa, Darmstadt 2011. 


\section{Opracowania}

Castritius H., Die Vandalen. Etappen einer Spurensuche, Stuttgart 2007.

Claude D., Der Millenarius [w:] Anerkennung und Integration. Zu den wirtschaftlichen Grundlagen der Völkerwanderungszeit 400-600, Hrsg. H. Wolfram, A. Schwarcz, Wien 1988, s. 17-20.

Claude D., Zur Ansiedlung barbarischer Föderaten in der ersten Hälfte des 5. Jahrhunderts [w:] Anerkennung und Integration. Zu den wirtschaftlichen Grundlagen der Völkerwanderungszeit 400-600, Hrsg. H. Wolfram, A. Schwarcz, Wien 1988, s. 13-16.

Courtois Ch., Les Vandales et l'Afrique, Paris 1955.

Delaplace Ch., La fin del'Empire romain d'Occident. Rome et les Wisigoths de 382 à 531 , Rennes Cedex 2015.

Díaz P.C., El reino suevo, Madrid 2011.

Durliat J., La salaire de la paix sociale dans les royaumes barbares ( $V^{E}-V^{\text {te }}$ siècles) [w:] Anerkennung und Integration. $\mathrm{Zu}$ den wirtschaftlichen Grundlagen der Völkerwanderungszeit 400-600, Hrsg. H. Wolfram, A. Schwarcz, Wien 1988, s. 21-72.

Eger Ch., Vandalisches Trachtzubehör? Zu Herrkunft, Verbreitung und Kontext ausgewählter Fibeltypen in Nordafrika [w:] Das Reich der Vandalen und seine (Vor-) Geschichten, Hrsg. G.M. von Berndt, R. Steinacher, Wien 2008, s. 183-196.

Goffart W., Barbarians and Romans. The Techniques of Accomodation, Princeton, New Jersey / Chichester, West Sussex 1980.

Halsall G., Barbarian Migrations and the Roman West, New York 2007.

Kampers G., Geschichte der Westgoten, Paderborn-München-Wien-Zürich 2008.

Le Bohec Y., Das römische Heer in der Späten Kaiserzeit, übersetzt von A. und G. Kolde, Stuttgart 2010.

Maier G., Amtsträger und Herrscher in der Romania Gothica. Vergleichende Untersuchungen zu den Institutionen der ostgermanischen Völkerwanderungsreiche, Historia Einzelschriften - 181, Stuttgart 2005.

Merrils A., Kingdom of North Africa [w:] The Age of Attila, ed. M. Maas, New York 2015, s. 264-281.

Merrills A., Miles R., The Vandals, Chichester 2010.

Modéran Y., Les vandales et l'Empire Romain, Arles 2014.

Pohl W., Migrations, Ethnic Groups, and State Building [w:] The Age of Attila, ed. M. Maas, New York, 2015, s. 247-263.

Rummel Ph. von, Where Have All the Vandals Gone? Migration, Ansiedlung und Identität der Vandalen im Spiegel archäologischer Quellen aus Nordafrika [w:] Das Reich der Vandalen und seine (Vor-) Geschichten, Hrsg. G.M. von Berndt, R. Steinacher, Wien 2008, s. 151-182.

Steinacher R., Die Vandalen. Aufstieg und Fall eines Barbarenreichs, Stuttgart 2016.

Strzelczyk J., Wandalowie i ich afrykańskie państwo, Warszawa 2005.

Torres Rodríguez C., El reino de los suevos, Santiago de Compostella 1977.

Vössing K., Das Königreich der Vandalen. Geiserichs Herrschaft und das Imperium Romanum, Darmstadt 2014.

Vössing K., Victor von Vita. Kirchenkampf und Verfolgung unter den Vandalen in Africa, Herausgegeben, eingeleitet und übersetzt von K. Vössing, Darmstadt 2011. 
Wilczyński M., Exercitus Barbarorum. Organizacja i działania wojsk ludów germańskich osiadlych w Vi VI wieku w basenie Morza Śródziemnego, „Vox Patrum” 35 (2015), t. 63, s. 287-305.

Wilczyński M., Gejzeryk i „,czwarta wojna punicka”, Oświęcim 2016.

Wilczyński M., Królestwo Swebów - regnum in etremitate mundi, Kraków 2011.

Wolfram H., Die Goten. Von den Anfängen bis zur Mitte des sechsten Jahrhunderts. Entwurf einer historischen Ethnographie, Aufl. 3, München-Wien 1990.

Wolfram H., Gotische Studien. Volk und Herrschaft im frühen Mittelalter, München 2005.

Wood I.N., The Barbarian Invasions and First Settlements [w:] The Cambridge Ancient History, 13: The Late Empire, AD 337-425, eds. A. Cameron, P. Garnsey, Cambridge 1998, s. 516-537. 